\title{
Aviation lecturers in the new normal world of learning
}

\author{
Arunya Pisitkasem ${ }^{1, *}$ \\ ${ }^{1}$ Aviation Business Management Program, College of Tourism and Hospitality, Rangsit University, \\ Thailand
}

\begin{abstract}
An aviation lecturer in the new normal world of learning have to understand the changes surrounding aneducational circumstance in the aspects of economy, society, politics, administration, environment, and technology, together with the pandemic of COVID-19 which causes a new normal way of living. The concept of new normal way of living are wearing face mask and carrying alcohol gel, enforcing social distancing measures, using technologies and digital system, decreasing social meeting or meeting in a small group instead, avoidingunnecessary touch, and giving precedence to health and hygiene. The aviation lecturers in the new normal world of learning need to understand the learning concept in the $21 \mathrm{st}$ century which focus on making learners achieve 21 st century skills, i.e., critical thinking\&problem-solving skill, creativity \& innovation skill, cross cultural understanding skill, collaboration/teamwork \& leadership skill, communications/information \& media literacy skill, computing \& ICT literacy skill, and career \& learning skill. Roles and duties of aviation lecturers have to be modified in many roles as a citizenship of the $21 \mathrm{st}$ century, a good member of a group, a co-leaner/co-investigator/guide or facilitator, an educational developer, a technology man, a creator of Professional Learning Community (PLC) and a professional aviation personnel. Necessary skills of aviation lecturer in the new normal world of learning include 21 stcentury skills, professional lecturer skill, learning design skill, multi teaching skill, critical thinking skill, technology skill, teamwork skill, communication skill, service skill/service mind, multicultural skill and aviation professional skill.
\end{abstract}

\section{Introduction}

The learning concept in the 21 st century has been developed by the Partnership for $21 \mathrm{st}$ Century Learning or P 21, which focuses to make learners achieve new skills of $21 \mathrm{st}$ century.Such concept has been developed in the Thai learning system, and becomes a new issue for educational personnel to develop and improve themselves, so they can develop learners to achieve new skills of 21 st century.

The pandemic of COVID-19 effects to all sectors, including the educational sector, were immense and never happen before. The concept of new normal way of living and the social distancing measure have been the important variables that make the change of learning

\footnotetext{
*Corresponding authors: arunya.p@rsu.ac.th
} 
program in the new normal of learning become more solid; however,lecturersare still a key mechanism for the process of executing.

"Lecturer" is a profession that is interested by aviation personnel to be their additional profession, profession after retirement, or secondary profession in the COVID-19 era.

At present, many higher education institutions, either private or public, have teaching programs that involve the aviation business, because of thegrowth of aviation industry in Southeast Asia. However, due to the context of learning program that has been changed into the concept of 21 st century learning, and together with the pandemic of COVID-19, teaching is more challenging to lecturers.Aviation lecturers have to develop theirdisciples to achieve the new skills of 21 st century under the teaching programs that conform to the new normal way of living and the social distancing measure.

This is an important issue that pushes aviation lecturers to be developed for the changed circumstances. Aviation lecturers have to develop their roles and skills to be in line with the new context of learning in 21 st century under the new normal way of living in order to develop their disciples and make them achieve new skills of 21 st century, together with qualities under the standard of national higher education.

Additionally, learners in the aviation subjectmust be ready to work under the international aviation standard. This article will describe about the change of educational circumstances, the new normal way of living, the concept of learning in 21 st century, the 21 st century skills, the roles of aviation lecturers, and the necessary skills of aviation lecturers in the new normal world of learning.

\section{The changes of educational circumstances}

From 20th century to 21 st century, there have been changes of circumstances in various aspects, such as economy, society, politics, administration, surroundings, environment, and technology, including the pandemic of COVID-19which is the important variables that push humans' way of living into the new normal and the social distancing measure, and such circumstances clearly affect learning programs. The changed circumstances can be concluded as follows:

1. Economical Circumstance. The pandemic of COVID-19 is causing a wide range of impact and together with the lockdown measure, these lead to a huge effect to the economic conditions, lacking of liquidity, decreasing of leverage ratio, or closing down of business. The population sector also faces with lacking of liquidity which causes chaining effect to other sectors, including the educational sector.Before the pandemic of COVID-19, [1] has predicted the global economic trends in 2050 that the group of countries that have an important role in directing the global economy will shift from developed countries, such as the United States, to emerging countries (E7), i.e., China, India, Brazil, Russia, Indonesia, Mexico and Turkey.Especially the case of China and India that the high-income population of which are increasing; consequently, the consumption rate are increasing accordingly, which is contrast to the circumstance in the United States, the economic leader at present, and the countries in Europe that are going into an aging society. Those countries will face the problems of labor shortage and decrease of consumption rate. Furthermore, the advancement of information technology makes the world become borderless, and the communication for an international trade can be done more convenient. All organizations run their businesses by using data and knowledge, and create innovations through research and development. The labor market sector has also changed qualifications of personnel. Personnel in this new era must have multi skills, and must be able to work immediately without training or teaching. The skills of analysis, problem solving and interaction between people will be wanted in the labor market more than the types of work that use physical strength because technologies have replaced such role already. The shift of power 
in the economic system as aforementioned is causing the changes of learning programs in every level, which is the fundamental structure of the population development to meet the economic circumstances that have been changed.

2. Social Circumstance.The society is entering into an aging society. The ratio of childhood population and working-age population are decreasing, and the aging population becomes majority. The condition of society becomes more urban. The compromising society is slowly fading, and get replaced by the competitive society. Generosity and relationship of people are lowering. The population relocation, either domestic or abroad, can be conveniently done, which leads to cultural diversity. The pandemic of COVID-19 has pushed the society into digital system in every sector, including the educational sector that has to conduct learning program through digital system, as well as a short-term curriculum that focuses on developing a specialized field of expertise through digital system. These have become more popular, and have changed the learning system completely. Therefore, it has become more challenging to aviation lecturers to get accustomed to digital system, and must be able to apply this into the new normal teaching programs.

3. Politics and Administration Circumstance. The trend of government reform; the interest and participation of people in politics; the accessibility to information and freedom to receive information relating to politics and administration; the convenience in receiving information throughmodern digital system; these factors have made people dare to criticize and give their opinions about politics and administration freely. The power has been transferred to people further under the inspection of local and international independent organizations. In the context of education, it is necessary to prepare young generation people to be readyfor changes in all aspects, and make them know how to think, analyze, and screen information to determine which information is right or wrong, so they can live peacefully in the new normal world.

4. Environment Circumstance. Climate change, global warming, increasing of air pollution, more frequently of severe natural disaster, reduction of necessary natural resources especially energy and food; the Paris Agreement has been made in 2020 due to such changes in order to implement the policy for the reduction of carbon dioxide from the world community (United Nation, 2018). On people sector, there are many projects to save the world, such as the green economy project that focusing on eco-friendly manufacturing and consumption [3]. Learning programs should be focused on making people understand things that happen, as well as encouraging appropriate conduct to the environment and developing consciousness ofjoint responsibility.

5. Technological Circumstance.In the period that COVID-19 spreads, technologies have come into an important role of living. Advancement of technologies has caused new innovations in every sector, including economy, society, communication, finance, banking, transportation, educational service, medical service, service business and entertainment business. Such developments have made the world narrower. The global connection of internet makes it fast and convenient to communicate in any place, and it gives birth to the social media \& social network. However, in some parts of society, an accessibility of technologies is limited, which results in an inequality to access technologies. The educational sector needs to give an opportunity to people to access technologies, develop their skills and expertise in using technologies as a part of living, make them catch-up to technologies and be able to choose the right technology that is suitable for occasions and circumstances.

The changes of educational circumstance as aforesaid are an important factor that pushes educational ideas to be developed according to the changed circumstance. Other than giving knowledge of aviation careers, aviation lecturers have to prepare to be a new generation people that can live peacefully in new normal way of living. 


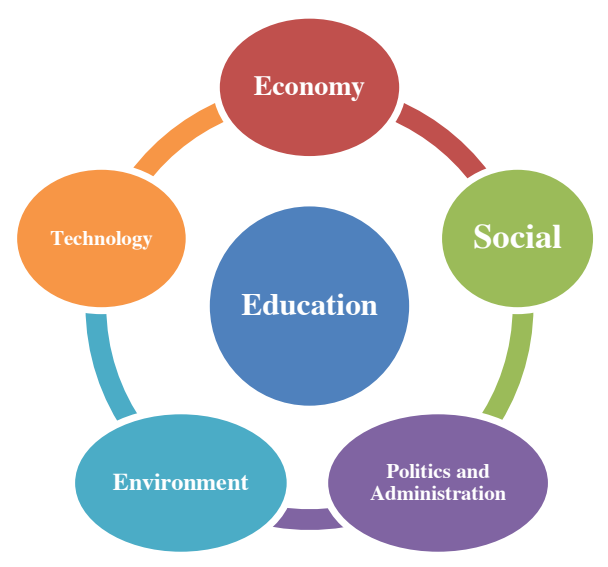

Fig. 1. Educational Circumstance.

\section{Concept of New Normal Way of Living}

The pandemic of COVID-19 is causing a wide range of impact to every sector around the world. Therefore, people need to change their way of living to make themselves safe and reduce the spread of virus. New normal way of living starts from a way of thinking, learning, communicating, performing and a new way of living. It is still unclear how long will this new normal way of living exist, but it tends to exist quite a while, and may cause permanently changes to people's behavior, and becomes social etiquette. The trends of the changed behaviors are as follows:

1. Wearing face mask and carrying alcohol gel become normal behavior in living in order to prevent infection and spreading virus to others;

2. Enforcing Social distancing measures, which change an interaction between people. Human touch is decreasing, which makes communication through technological systems have more roles;

3. Using technologies and digital systems become an important skill for living. Every sector uses technological systems to support its task, which stimulates people to learn how to use technologies;

4. Decreasing Social meetings or meeting in a small group and only on a necessary basis, as it can be seen from the business sector that adopts work from home policy, holds a meeting through digital systems, as well as the goods consumption of people;

5. Avoiding unnecessary touch, as it can be seen from the western greeting culture that has been changed from hugging, hand-shaking or kissing to saluting or elbow-touching for the avoidance of touch;

6. Giving precedence to health and hygiene, People tend to eat food that is nutritious, safe, clean, and natural, as well as exercise to build up immunity.

Under the concept of new normal way of living, aviation lecturers have to be a role model and develop their disciples to be able to live in a new normal way [4]. In the context of education in the new normal world, aviation lecturers in higher education institutions still have to: 1) make people achieve new skills for living and working; 2) give knowledge to society through researching and developing to fulfil the needs of people at global, national, regional, local and community level. 3) generate new innovation into action. Moreover, aviation lecturers in higher education institutions have an important role to 
develop their disciples to have qualities of being 21 st century people; therefore, aviationlecturers need to understand the concept of learning in 21 st century.

\section{Concept of Learning in 21st Century}

The Partnership for 21 st Century Skills has proposed the concept of learning in 21st century, which focuses on making learners achieve new skills of 21 st century. To achieve that, learners need to have knowledge and understanding in the core subjects, i.e., the important languages of the world (English, reading skill or art of using language), arts, mathematics. economics, science, geography, history, administration, and citizen duty. Learners need to have deep understanding in such subjects, develops themselves to be an expert, and must be able to apply those into the skills of living in 21 st century, i.e., the learning and innovation skills, information media and technology skills, and life and career skills. Such skills can be created from learning programs with supporting systems for learning that managed by the person concerned in the learning program, such as educational institutions, administrators, teachers/lecturers, parents and disciples. 21 st century of education support systems consist of 21 st century standards and assessments, 21 st century curriculum and instruction, 21 st century professional development, and 21 st century learning environments [5].

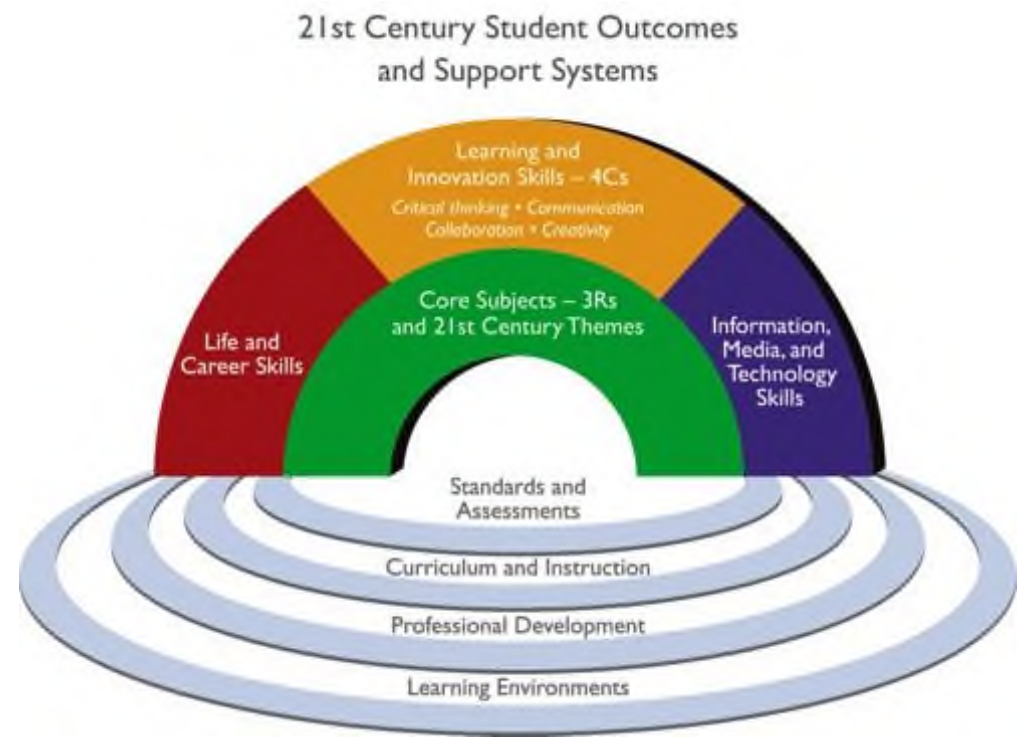

Fig. 2. The Partnership for $21^{\text {st }}$ Century Skills Framework for $21^{\text {st }}$ Century Learning. Source: [5].

From the context of learning in 21 st century, aviation lecturers in the new normal of learning need to have deep understanding in such issue because it may be different from before. However, to make learners achieve the 21 st century skills, aviation lecturers in the new normal world of learning have to create a learning program that conforms with the concept of learning in 21 st century.Aviation lecturershave to develop themselves to have such skills beforehand, so they can be a role model, and develop disciples to achieve the 21 st century skills.

From the concept of learning program in 21st century, Prof. Vicharn Panich [6] briefly said that the necessary skills of living for 21 st century people must include $3 \mathrm{R}$ skills, i.e., reading, writing and arithmetic, and the new skills of 21 st century are $7 \mathrm{C}$ skills, which consist of: 
1. critical thinking \&problem-solving skill, which is the skill of reasoning, systematical thinking, logical deciding, and reasonable problem solving;

2. creativity \& innovation skill, which is the skill of creativity, ability to search for new ideas or methods, and practical followable;

3. cross cultural understanding skill, which is the skill of understanding the variety anddifference of people, respecting personal rights, and ability to work and live with dissimilar person properly;

4. collaboration/teamwork \& leadership skill, which is the skill of working with others, compromising for mutual target, and having responsibility with the team;

5. communications/information \& media literacy skill, which is the skill of ability to communicate understandably, and ability to communicate in various forms, such as speaking, writing, and gesturing;

6. computing \&ICT literacy skill, which is the skill of using ICT proficiently, ability to access sources of information properly, and ability of using ICT morally and legally;

7. career \& learning skill, which is the skills of adapting to changes, being flexible, managing time wisely, working and learning independently for self-development.

Aviation lecturers have a very vital role to apply such skills into learning programs, as well as curriculums development, teaching methods development, evaluation development and supporting systems for learning development to make learners become a people in the 21 st century.It's a mighty responsibility. Therefore, the roles and duties of aviation lecturers have been changed from before.

Roles and duties of aviation lecturers

The Higher Education Standards in Thailand has set the standards of higher education institutes in 5 aspects: 1) Learners outcomes aspect. Expectation results: learners can support themselves, collaborate creatively with others, and be a robust citizen. 2) Research and innovation aspect. Expectation results: research and innovation in response to the national strategy 3)Academic services Aspect. Expectation results: be consistent with the context and address local needs community and society. 4)Art, Culture and Thai identity aspect.Expectation results: proud to be Thai, knowledge and understanding of Thai's art and culture, get more opportunities and added value to learners, community, social and nation. and 5) Educational management aspect.Expectation results: integrated teaching and learning management, accomplish the institute's mission and vision, and efficient and effective quality assurance system $[7,8]$. According to such standards,lecturers are a key mechanism for the process of executing. So, we can conclude that Aviation Lecturers have duties as follows:

1. Producing graduates through learning programs of lecturers;

2. Researching and developing, creating innovations;

3. Providing academic services to society; and

4. Conserving art and culture, and preserving national art and culture.

As a result of changes in the concept of learning, roles and duties of lecturers need to be changed in accordance with the new context of learning in 21 st century. Prof. Dr. Chaiyong Promwong [9] said that the roles of lecturers will be changed into 2 ways, i.e., parental lecturer and learning supporter. It means that, to be a parental lecturer, lecturers have to look for learners' behavior, take care, help, give instruction in studying and adaptation, and solve their lives' problems. Classrooms should be regarded as a home for students to depend on before facing the real experience outside. To be a learning supporter, lecturers will help their disciples by explaining tasks and works that need to be done, encouraging them and giving opinion for an improvement of their works.

Aviation lecturers in higher education institutions should have the following roles:

1. Beinga citizenship of 21 st century.To achieve that, aviation lecturers need to develop themselves to achieve all-around skills, such as the skills of analyzation, technology usage, 
working with other people or people from different cultures, creativity, compassion, empathy, accepting the difference, respecting others' opinions and allowing others to give opinions, so they can be a good role model to their disciples;

2. Being a good member of a group and cooperating with a group, such as university, faculty, major, classroom, community and society, with the target of having disciples succeed in learning, and for the public interest of society and nation;

3. Being a co-learner/co-investigator/guide or facilitator. Emphasizing the idea of teach less and learn more or active learning that focus on learning process more than content of subjects; for example, PBL - Problem Based Learning, TBL - Team Based Learning, Activity Based Learning or Case Study Based Learning. The target of this is to help learners achieve the skills of critical thinking, creativity, solving problems according to situations, working with others and self-directed learning, and make them achieve $21 \mathrm{st}$ century skills;

4. Being a developer, and developing themselves to have multi skills, and also developing curriculums, learning contents, activities for learning, teaching methods, evaluation methods of learning result, as well as developing themselves in various aspects to have learning programs, designation of learning environment and evaluation of learning result that conform with the concept of learning in 21 st century [10];

5. Being a technology man, which is an important role in the era that COVID-19 spreads. Aviation lecturers need to have technological skill and be able to combine original teaching method or teaching in a classroom with an online class, as well as developing digitalization of instruction medias and teaching documents;

6. Being a creator of Professional Learning Community (PLC) by cooperating with others in higher education institutions, such as administrators, scholars and other personnel. They should work as a team, aviation lecturers should be in a role of leader, and administrators, scholars and other personnel should be in a role of supporter, for the best quality of teaching and long life learning that focus on learning result of disciples;

7. Being a knowledgeable and skillful aviation personnel that strictly follows the rules, has safety awareness, professional service skills, virtues, morals, and professional ethics.Being a good role model for disciples at working in the aviation business.

In the book named "New Paradigm of Education: A Perspective on 21st Century Education" (2013),

Assoc. Prof. Dr. Wiroj Sarattanahas compiled the ideas of new skills of teachers/lecturers in 21 st century as follows:

WordPress.com has mentioned about the changes of the new paradigm of education that teachers/lecturers have to change from being a knowledge distributor into a learning author that helpslearnerstransform information into learning, and transform knowledge into wisdom. Teachers/Lecturers need to have the following skills: collaboration skill, critical thinking skill, oral communication skill, written communication skill, technology skill, citizenship skill, learn about careers skill and content skill.

Churches has mentioned 8 characters of teachers/lecturers in 21 st century as follows: adapting, being visionary, collaborating, taking risk, long life learning, communicator, modeling behavior and leading.

From the ideas as mentioned above, aviation lecturers in the new normal world of learning should have the following skills:

1. 21 stcentury skills. Aviationlecturers need to have 21 st century skills, which are $3 \mathrm{R}$ and 7C skills, for the sake of supporting and developing learners to achieve such skills. Furthermore, aviation lecturers also have to be a good role model for their disciples;

2. Professional lecturer skills. Theseare the skills to perform duties as lecturers in higher education institutions that have to produce graduates through learning programs, do researches or produce academic performance, provide academic services to society, 
conserve art and culture, preserve national art and culture, be able to adapt and develop themselves, improve their behavior and attitude to conform with learning environments that change all the time, and mainly consider the target of education for the benefit of society;

3. Learning design skill with cooperation of learners to have learning programs that are suitable with content of subjects and various characteristics of disciples, and to use existing resources to support learning programs;

4. Multi teaching skill. This is challenging for aviation lecturers in 21 st century. According to the vision of Singapore that has been described by Robin Fogarty and Brian M. Pete in the book named " 21 st Century Skills: Rethinking How Students Learn" [5], teach less and learn more is a clear style of teaching method in 21 st century. Teachers should lessen the old style of teaching, speak less, lessen the knowledge push, lessen oneway communication, and use various styles of teaching instead, such as practicing, cooperative responding, interacting, learning through media, learning through case studies,project-based learning, as well as using learning evaluation method that conforms with the changed form of learning;

5. Critical thinking skill. This is the basic skill that is important in the new normal world. Aviation lecturers need to have such skill in order to understand how to teach it to learners;

6. Technology skill. Technology information is an important tool in working in the aviation industry and also a necessary skill for 21 st century; therefore, aviation lecturers need to have such skill for teaching and working;

7. Teamwork skill. According to the concept of learning in 21 st century, results will only be achieved through cooperation of various groups of people, such as policy makers, school administrators, teachers, students, parents, and community, in order to create the professional learning community;

8. Communication skill. This is the skill of communication, such as the skill of speaking, reading, writing, presenting, as well as the native language skill and the world's language skill (English language).

9. Service skill/Service mind. This is the heart of working in the aviation industry. It's a huge responsibility for aviation lecture to be a role model so that learners will absorb such skill;

10. Multiculturalskill.This is a working environment in the aviation industry; therefore, aviation lecturers have to cope with and make learners accustomed, and be able to work with people from different cultures;

11. Aviation profession skill. This is the skill of an aviation professional. Some positions need to have a license to show that this person is allowed for such work, and to pass on skills and spirit of working in aviation business.

These skills are necessary for aviation lecturers in the new normal worldof learning. Moreover, aviation lecturers need to have virtues,morals and basic professional ethics of teacher/lecturer profession, in order to produce quality aviation personnel.

\section{Conclusion}

To be an aviation lecturer in the new normal of learning, aviation lecturers have to be aware of the changes in circumstances of various aspects, such as economy, society, politics, administration, environment, and technology, including the pandemic of COVID-19which hugely affects all sectors, including the educational sector. In order to develop their own teaching program, aviation lecturers have to understand the concept of learning in $21 \mathrm{st}$ century, which focuses on making disciples achieve new skills of 21 st century.

According to the pandemic of COVID-19, the new normal way of living has been arisen. Aviation lecturers have to understand and be a role model of the new normal way of 
living so that the new normal of learning can be prepared properly. Beside the aviation knowledge, aviation lecturers also need to understand the 21 st century skills for the development of themselves and their disciples to be able to achieve such skills. The roles and duties of aviation lecturers need to be modified.Aviation lecturers may perform in various roles according to different situations for learning. They have to develop themselves constantly in order to have the 21 st century skills, to be a professional aviation personal,and also to be a professional aviation lecturer.It's a great responsibility for aviation lecturers in the new normal of learning.

\section{References}

1. Pricewaterhouse Coopers 2015 The world in 2050 will the shift in global economic power continue? (2020) https://www.pwc.com

2. United Nations 2015 The Paris Agreement (2020) https://unfccc.int/process-andmeetings/the-paris-agreement/the-paris-agreement

3. Education Department, Sukhothai Thammathirat University, Education in $21^{\text {st }}$ Century (The Aspire Group, Nonthaburi, 2013)

4. H.L.T. Mai et al., International J. of Recent Technology and Engineering 8(2.11), 3876-3882 (2019)

5. J. Bellanca, R. Brandt, $21^{\text {st }}$ Century Skills: Rethinking How Students Learn (Solution Tree Press, USA, 2010)

6. V. Panich, Guidelines for Creating learning for disciples in the $21^{\text {st }}$ Century (Tathaka Publication Co, Bangkok, 2011)

7. Ministry of Education 2018 Higher Education Standards http://www.ratchakitcha.soc.go.th/DATA/PDF/2561/E/199/T19.PDF

8. A.H. Tran et al., International J. of Recent Technology and Engineering 8(2.11), 38833888 (2019)

9. C. Promwong, The Future of Educational Management in Thailand

10. M.M. Ihnatenko et al., International J. f Economics and Business Administration 7(2), 290-301 (2019) 